\title{
Yolanda Dreyer: Haar proses van bewusmaking -'n Waarderende refleksie op haar bydrae tot die akademiese diskoers ten opsigte van die temas gender, huwelik en seksualiteit
}

\begin{tabular}{|c|c|}
\hline \multicolumn{2}{|c|}{$\begin{array}{l}\text { Author: } \\
\text { Annelie Botha }{ }^{1}\end{array}$} \\
\hline \multirow{2}{*}{\multicolumn{2}{|c|}{$\begin{array}{l}\text { Affiliation: } \\
{ }^{1} \text { Department of Practical } \\
\text { Theology, Faculty of } \\
\text { Theology, University of } \\
\text { Pretoria, South Africa }\end{array}$}} \\
\hline & \\
\hline \multicolumn{2}{|c|}{$\begin{array}{l}\text { Research Project Registration } \\
\text { Project Leader: Y. Dreyer (D) } \\
\text { Project Number: } 2546930\end{array}$} \\
\hline \multicolumn{2}{|c|}{$\begin{array}{l}\text { Description: } \\
\text { Dr Botha is participating in the } \\
\text { research project, 'Gender } \\
\text { Studies and Practical Theology } \\
\text { Theory Formation', directed } \\
\text { by Prof. Dr Yolanda Dreyer, } \\
\text { Department of Practical } \\
\text { Theology, Faculty of Theology, } \\
\text { University of Pretoria. }\end{array}$} \\
\hline \multicolumn{2}{|c|}{$\begin{array}{l}\text { Corresponding author: } \\
\text { Annelie Botha, } \\
\text { abothaster@gmail.com }\end{array}$} \\
\hline \multicolumn{2}{|c|}{$\begin{array}{l}\text { Dates: } \\
\text { Received: } 23 \text { June } 2017 \\
\text { Accepted: } 14 \text { July } 2017 \\
\text { Published: } 29 \text { Sept. } 2017\end{array}$} \\
\hline \multicolumn{2}{|c|}{$\begin{array}{l}\text { How to cite this article: } \\
\text { Botha, A., 2017, 'Yolanda } \\
\text { Dreyer: Haar proses van } \\
\text { bewusmaking -'n } \\
\text { Waarderende refleksie op haar } \\
\text { bydrae tot die akademiese } \\
\text { diskoers ten opsigte van die } \\
\text { temas gender, huwelik en } \\
\text { seksualiteit', HTS Teologiese } \\
\text { Studies/Theological Studies } \\
\text { 73(4), a4714. https://doi. } \\
\text { org/10.4102/hts.v73i4.4714 }\end{array}$} \\
\hline \multicolumn{2}{|c|}{$\begin{array}{l}\text { Copyright: } \\
\text { (C) 2017. The Authors. } \\
\text { Licensee: AOSIS. This work } \\
\text { is licensed under the } \\
\text { Creative Commons } \\
\text { Attribution License. }\end{array}$} \\
\hline Read online & \\
\hline 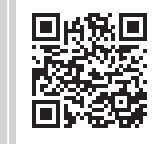 & $\begin{array}{l}\text { Scan this QR } \\
\text { code with your } \\
\text { smart phone or } \\
\text { mobile device } \\
\text { to read online. }\end{array}$ \\
\hline
\end{tabular}

\begin{abstract}
The focus of this reflection on Yolanda Dreyer's contribution to the academy is her research on gender, sexuality and marriage. The contributions she has made were written from a pastoral perspective and focused on pastoral interaction with women. The issues surrounding the church's view on marriage does not only concern the roles given to women but also the place and status that the church and society assigned to marriage as an institution. Her contribution in the area of sexuality is very closely linked to the insights she provides in her research on homosexuality. How sexuality is seen has an impact on how homosexuality and heterosexuality are reflected on.
\end{abstract}

\section{Inleiding}

Yolanda Dreyer se akademiese bydrae tot die gesprek oor die huwelik, gender en seksualiteit, begin reeds met haar ongepubliseerde BD-skripsie getiteld; Pastorale berading en die Pastorale Verwysingsdiens: ' $n$ Kritiese evaluering (1980). In haar DD-proefskrif met die titel Pastorale interaksie met vroue. 'n Prakties teologiese begronding (1998), begin sy met 'n proses van bewusmaking. Die bewusmaking fokus op die feit dat vroue se ervaring asook die waarde wat vroue toeken aan hulle eie ervaring nie die fokus van pastorale interaksie met vroue is nie. Die probleemstelling is gegrond daarop dat pastorale werk met vroue in die kerk uitsluitlik deur mans gedoen was. Pastoraat het plaasgevind vanuit 'n manlik-gedomineerde kerk en leefwêreld (Dreyer 1998a:6).

Waar haar proses van bewusmaking aanvanklik gefokus was op die rol wat aan vroue binne die kerk en huwelik toegeken is, het haar fokus verbreed om ook ander gemarginaliseerdes in te sluit. Sedert die begin van haar akademiese verbintenis aan die Universiteit van Pretoria tot vandag het sy met haar navorsing op die terreine van die huwelik, seksualiteit en gender 'n bydrae gelewer wat bygedra het tot die verskuiwing in denke ten opsigte van die rolle wat aan vroue toegeken word binne die kerk en huwelik en die breër samelewing. Haar publikasies op die gebied van seksualiteit bring insigte wat tot vernuwing lei en volgens my, aanleiding gegee het tot die besluit wat die Nederduitsch Hervormde Kerk van Afrika in Oktober 2016 geneem het rakende homoseksualiteit.

Die fokus van hierdie refleksie op Yolanda Dreyer se bydrae tot die akademie is vir die doeleindes van die Festschrift gerig spesifiek op haar bydrae tot die gebiede van gender, seksualiteit en die huwelik. Ek dra hierdie artikel aan haar op as blyk van my waardering vir haar as akademikus en ook as blyk van my waardering vir haar as vriendin. Wanneer ek in hierdie artikel na haar verwys gaan ek nie haar van gebruik nie, maar haar voornaam. Sy is nie die objek van die studie nie, maar die subjek. Dit is in pas met Yolanda se gebruik van Habermas ([1981] 1984) se kommunikatiewe handelingsteorie. In die kommunikatiewe handelingsproses is die ontmoeting een van subjek met subjek (Dreyer 1998a:25).

\section{Gender}

Die bydrae wat Yolanda Dreyer gelewer het op die gebied van gender kan nagespoor word in akademiese artikels wat sy geskryf het vanuit 'n pastorale perspektief, gefokus op pastorale interaksie met vroue. Yolanda, soos ander wat navorsing doen in hierdie gebied, tref 'n onderskeid tussen die terme sex en gender. Die term sex verwys na die biologiese geslag van 'n persoon en gender verwys na geslag as sosiale konstruk (Dreyer 1998a:8). Gender verwys na die rolle en waardes wat deur die dominante sisteme van 'n samelewing aan mans en vroue 
toegeken word. Yolanda verwys hierna as onder andere die sosio-kulturele narratief:

'n Sosio-kulturele narratief orden die samelewing. Dit weerspieël die waardes van die samelewing en definieer rolle vir die onderskeie persone in hulle onderskeie posisies ... Die sosiokulturele narratief verteenwoordig die dominante waardesisteem van die samelewing ... Die dominante waardesisteem behels die waardes van en beskerm die belange van die dominante groep. Sosio-kulturele narratiewe is uitdrukking van die heersende ideologie in 'n kultuur. (Dreyer 1998a:201)

Die heersende ideologie in die Westerse kultuur was met die aanbreek van die postmoderne era patriargaat. ' $n$ Patriargale samelewing is hiërargies (kyk Dreyer 1998a:349). In 'n patriargale sisteem is daar duidelik gedefinieerde geslagsrolle (Dreyer 1998a:149-150). Die patriargale sisteem kan teruggevind word in die Mediterreense kultuur van die Bybel (kyk Dreyer 1999a:48-69).

As reformatories teoloog is die gebruik van die Skrif as oriëntasie-punt vir die pastoraat met vroue en die bewusmakingsproses ten opsigte van die invloed van gender-rolle en die patriargale sisteem op vroue, vir Yolanda belangrik en vanselfsprekend (Dreyer 1999a:48). Sy gee aandag aan die saak van gender deur gebruik te maak van verskillende temas soos verwoord deur die titels van haar akademiese artikels.

Ek gaan vervolgens ' $n$ kort waarderende refleksie aanbied op enkele van die artikels waarin sy na my mening op hierdie manier 'n bydrae gelewer het ten opsigte van gender.

\section{Pastorale interaksie met vroue gesien vanuit die beelde wat vir God gebruik word}

Die eerste woorde van die artikel is ook die woorde waarmee Yolanda haar DD-proefskrif met die titel; Pastorale interaksie met vroue. 'n Prakties teologiese begronding (1998) begin (kyk Dreyer 1998a). Die woorde waarmee die artikel begin word, is die woorde waarmee dr. Christie Cozad Neuger in 1989 die eerste lesing van die herfssemesterkursus, wat Yolanda bygewoon het, Pastoral care and counseling with women, aan die Princeton Theological Seminary in die VSA, begin het: 'Do no more harm'. Die veronderstelling onderliggend aan hierdie woorde is dat wanneer vroue by 'n pastor kom hulle reeds aan skade blootgestel was. Die appèl tot die pastors is dat hulle nie verder sal bydra tot die skade nie (Dreyer 1998b:544).

Pastors word daarvan bewus gemaak dat hulle in hulle pastorale interaksie met vroue skade kan aanrig. Die moontlikheid dat pastors kan skade aanrig is geleë in die feit dat pastorale werk met vroue ten tye van die verskyning van die artikel hoofsaaklik deur mans gedoen is en vroue wat wel pastorale werk gedoen het geïnstitusionaliseer was binne 'n manlik-gedomineerde wêreld. Pastorale interaksie met vroue is beïnloed deur die uitsluitlik manlike perspektief en 'n manlik gedomineerde wêreld (Dreyer 1998b:544-545). Die ervaring van vroue was nie die fokus van pastorale interaksie met vroue nie. Pastors moes bewus gemaak word en in staat gestel word om 'vroue se volle mens-wees voor God te respekteer' (Dreyer 1998b:545)

Vir Yolanda is daar ' $n$ noue korrelasie tussen Skrifbeskouing, Godsbeelde en die identiteit van vroue. Godsbeelde beïnvloed ' $n$ mens se relasie met ander asook ' $n$ mens se selfverstaan (Dreyer 1998a:55). Sy stel dit soos volg:

Die dominante Godsbeelde van die geloofsgemeenskap het 'n uitwerking op die vorming van 'n positiewe of negatiewe identiteit. Dit het weer'n effek op die gemeenskap se houding en optrede teenoor (A)nder. (Dreyer 1998b:547)

Sy toon aan hoe die uitsluitlik manlike taal en beelde vir God wat in die kerk en teologie vir God gebruik word 'n invloed het op die manier hoe vroue oor God praat en God ervaar en hoe vroue hulle self ervaar. Wanneer daar oor God gepraat word, gebruik mense beelde en taal wat kom uit hulle eie ervaringswêreld. Sy plaas die vraag op die tafel of dit in die lig hiervan aanvaarbaar sou wees om oor God te praat in terme en beelde uit vroue se leef- en ervaringswêreld. Saam met Bonhoeffer (1967:360) en Buber ([1953] 1988:16-17) stel sy dat God nie vasgevang kan word in mensgemaakte konstrukte en konsepte nie. Die leer van die kerk oor God stel dat God nie manlik of vroulik is nie, dat God nie'n geslagtelike wese is nie. Wanneer daar in die kerk uitsluitlik manlike beelde en taal vir God gebruik word, het dit die effek dat God geassosieer word met alles wat manlik is en nie met wat vroulik is nie. Dit het ' $n$ invloed op die waarde wat aan vroue toegeken word. Sy vra vir die verbeelding van God in vroulike metafore:

Wanneer daar ter wille van vroue se geestesgesondheid, volle positiewe identiteit as persone en gelowiges gevra word na die verbeelding van God kragtens vroue metafore, gaan dit nie om ontologiese eienskappe van God nie. Dit gaan oor die wyses waarop vroue God ervaar en die effek wat dit op hulle lewens het ... (Dreyer 1998b:549)

In die Christelike erfenis van spreke oor God is dit ' $n$ feit dat dit net mans was wat vanweë die institusionalisering binne die patriargale samelewing mag en reg gehad het om te praat en te skryf oor God, met die gevolg dat manlike woorde en beelde van God die botoon voer in die spreke oor God (Dreyer 1998b:549). Yolanda toon ook aan hoe daar in die liturgie en taal van die kerk manlike voornaamwoorde en taal gebruik is om na christene in die algemeen te verwys. In die weergawe van die Afrikaanse gesangboek in die kerk wat ten tye van die skryf van haar artikel in gebruik was, moes vroue saam sing, gedra jou manlik sterk en moedig (Dreyer 1998b):

'n Erfenis wat die man en alles wat manlik is, voorhou as die norm vir menswees, beteken vir mense wat nie aan daardie norm voldoen nie, dat hulle waarde en moontlikhede minder is. (bl. 550)

Yolanda toon aan dat die skade wat vroue ervaar op die gebied van godsdienstige sosialisering en identifikasie, direkte negatiewe gevolge het vir hulle identiteitsvorming. Sy haal Schertzberg (1995:79) in die verband aan:

Männlichen Menschen steht trotz aller Untersheidenheit zwischen Mensch und Gott en männliches Gottesbild zur 
Identifikation offen, weiblichen Menschen ist dies nicht möglich. (Dreyer 1998b:552)

Sy toon aan dat die beelde van God as Koning en Heer anakronistiese beelde is wat nie meer relevant is vir die tyd waarin ons leef nie. Vroue kan nie met hierdie beelde identifiseer nie. Die beeld van God as Vader kan negatief beleef word wanneer ' $n$ dogter ervaar hoe haar pa haar molesteer. Dit plaas gelowiges ook in ' $\mathrm{n}$ kinderrol. Dit is skadelik vir vroue wat die rol van mindere en minderjarige, wat deur die samelewing van die tyd aan vroue toegeken is, wil ontkom. Die metafoorelement gaan verlore as gevolg van die eksklusiewe gebruik daarvan. Die gebruik van die beeld van God as Vader behoort volgens haar te fokus op God se vaderliefde, God se liefde wat weerloos, teer en heelhartig is (Dreyer 1998b:560).

Yolanda bepleit die gebruik van nie-patriargale Godsbeelde. Die beeld van God as vriend, in vriendskap, is daar nie ruimte vir hiërargie en ongelykheid nie. Die beeld van God as moeder in die Bybel toon hoe God, God se mense versorg en genees, geboorte gee, lewe gee aan mense (kyk Dreyer 1998b:564-565).

Die bewusmakingsproses by die pastor is vir haar daarop gerig dat die pastor die vrou as volledige persoon in eie reg sal sien en dat die pastor vroue sal kan begelei tot waardering van hulle God-gegewe waarde, eie identiteit en egte ervaring van hulle persoonskap (Dreyer 1998b:569).

\section{Die personaliteit van vrou-wees binne die Mediterreense kultuur}

Hierdie artikel beklemtoon die noodsaaklikheid daarvan dat pastors, wat opleiding het in die Bybelwetenskappe en daarom bewus is van die gaping tussen die moderne Westerse-kultuur en die Mediterreense kultuur in die eerste eeu, die kennis en betekenis daarvan vir die lewe en geloof van vroue in ag sal neem, wanneer hulle pastoraal met vroue werk. In hierdie artikel verduidelik Yolanda wat met die begrip kultuur bedoel word. Sy toon ook aan hoe die Mediterreense kultuur van patriargie die sosiale identiteit van vroue bepaal het (Dreyer 1999a:48).

Sy (Dreyer 1999a:48-49) is dit eens met Dianne Jacobs-Malina (1993) dat die Hebreeuse epiese literatuur, die Griekse filosofie en die Romeinse reg wat verweef is met patriargale dominansie irrelevant geword het vir Christene en ook nie meer aangewend kan word as agtergrond en motivering vir rolle wat aan vroue toegeken word in die samelewing en huwelik nie. Dit is nodig om in die Skrif die sake te vind wat tyd en kultuur oorstyg. Die doelwitte en norme van die evangelie is vir haar dit wat relevant bly vir menslike gedrag. Die Antieke kultuur en sosiale gebruike kan volgens haar nie beskou word as normatief en in die eietydse geskiedenis oorgedra word nie.

Yolanda kies in haar Skrifbeskouing vir 'n feministiese hermeneutiek wat vra vir die ommekeer van sosiale rolle en vir 'n betrokke hermeneutiek wat ' $n$ bewusmakingsproses is met betrekking tot die skade wat aan vroue berokken kan word as gevolg van manlike oorheersing. Sy kies vir dit wat sy die 'Jesus-saak' noem as haar uitgangspunt vir pastoraat met vroue (Dreyer 1999a:49-50; kyk 1998a).

Yolanda se verstaan van wat kultuur, is dialekties georiënteer. Die dialektiek verstaan die verband wat daar is tussen die teoretiese (sisteem van simbole) en die praktiese (sosiale gedrag). Sy stel dit soos volg:

'n Mens kan kultuur sien as 'n georganiseerde sisteem van simbole waarvolgens ' $n$ spesifieke en sosiaal-bepaalde stel betekenisse en waardes aan persone, dinge en gebeurtenisse toegeken word. Kulture skep patrone van gedeelde betekenis en gevoel. Hierdie patrone vorm op hulle beurt die sosiale wêreld van 'n spesifieke groep mense ... Simbole ken betekenis en waarde (gevoel) op só 'n manier aan, mense, dinge en gebeurtenisse toe dat al die lede van 'n gegewe groep hierdie betekenis en waardes gewoonlik onkrities aanvaar, met mekaar deel en op 'n manier uitleef ... Daarom bepaal die kultuur en sosiale sisteem waarbinne 'n persoon leef, onbewustelik sy of haar beskouing van die lewe en die werklikheid ... (Dreyer 1999a:50-51)

Die kerke in die Reformatoriese tradisie in Suid- Afrika beskou die Bybel as normatief vir 'n gelowige se lewe. Hoe hierdie norm geïnterpreteer en toegepas word, het gevolge vir die lewe van elke gelowige. Die interpretasie van tekste uit ' $n$ kultuur wat drasties verskil van die kultuur van die interpreteerder vereis insig in hoe die kultuur wat geïnterpreteer word, funksioneer en wat die onderliggende waardesisteme van die kultuur is. Die kultuur en waardesisteme kan nie kritiekloos toegepas word in die eie wêreld nie (Dreyer 1999a:51).

Dit is daarom vir haar belangrik dat wanneer daar pastoraal met vroue gewerk word en die Bybel as norm vir die gesprek dien, die pastor insig behoort te hê in die rolle en plek in die familie en samelewing wat deur die Mediterreense kultuur aan vroue toegeken is. Daardie rolle kan nie onkrities gekontinueer word nie.

In haar proses van bewusmaking bring Yolanda dit onder die aandag dat die antieke Mediterreense samelewing die wêreld in terme van geslag gesien het:

Die plek, posisie, rolle en waarde van persone binne die familie was deur geslag bepaal. Mens was gedefinieer op grond van hulle geslag en geslagsrolle. Arbeid was verdeel op grond van geslag. Beweegruimte - hoe vryelik 'n persoon mag beweeg en waarheen hy of sy mag beweeg - was bepaal op grond van geslag. Die geslag-georiënteerde familie het gedien as die basiese struktuur waarvolgens die Mediterreense samelewing georden was. Die skeiding op grond van geslag tussen manlike en vroulike rolle het een van die mees sentrale kulturele waarde in Palestina tydens die eerste eeu gevorm. (Dreyer 1999a:53)

In die patriargale familie was die vader die verteenwoordiger van God en alle verhoudings is hiervolgens ingerig. Volgens hierdie sosiale sisteem was mans beter as vroue. Die ongelykheid tussen man en vrou word binne die tradisionele patriargale siening begrond in die skeppingsorde. 
Binne hierdie sosiale sisteem was daar gedrag wat as tipies manlik en tipies vroulike gedrag bestempel is. Manlike waardes en gedrag was moed, gesag, beskerming van die familie se eer, besorgdheid oor aansien en sosiale onafhanklikheid. Vroulike waardes en gedrag was skaamheid, om te bloos, skugterheid, terughoudendheid en seksuele eksklusiwiteit. Mans wat optree soos 'n vrou en enige iets doen wat deel is van ' $n$ vrou se rol, het 'n grens wat ten strengste gehandhaaf was, oorskry. Dit het 'n man sy eer gekos. Eer en skande was sleutelwaardes vir die verstaan van die leefwêreld van die Bybel. Eer het tot die sfeer van die man behoort en skande tot die sfeer van die vrou. Manlike eer en vroulike skande is gesimboliseer deur hulle geslagsorgane (kyk Dreyer 1999a:58-59).

Daar word slegs positief gepraat oor vroue binne die konteks van die huwelik en moederskap. Solank as die vrou haar hou aan die ondergeskikte rolle en reëls wat voorgeskryf is aan die vrou, binne die huwelik, word vroue deur mans geprys. 'Die ideale stand van sake vir ' $n$ volwasse vrou in die antieke Mediterreense samelewing was om in die huwelik te tree' (Dreyer 1999a:59). Die rol van die vrou was dié van 'n afhanklike. Vroue was eers afhanklik van hulle pa's, later van hulle mans en nog later van hulle seuns:

Sonder ' $n$ seun het ' $n$ vrou geen kans op erkenning van haar persoonskap nie en as haar man sterf en daar nie ' $n$ ander manlike substituut in haar man se familie was nie, het sy ' $n$ (almanah) [stemlose] weduwee geword. (Dreyer 1999a:59-60)

Yolanda se navorsing oor die personaliteit van vrouwees binne die Mediterreense kultuur is begrond op 'n deeglike kennis van wat kenners op die gebied van die sosiale wetenskap bevind het. Sy maak gebruik van onder andere die werk van Countryman ([1988] 1989), Jacobs-Malina (1993), Matthews en Benjamin (1993) en Malina ([1981] 1993), om maar enkeles te noem.

Yolanda se proses van bewusmaking ten opsigte van die rol van vroue binne die kultuur en leefwêreld van die Nuwe Testament, het die implikasie dat hierdie rolle gesien moet word vir wat dit is, sosiale konstrukte vanuit die antieke wêreld wat nie meer in die pastorale interaksie met vroue aangebied kan word as riglyn waarvolgens hulle moet leef en optree nie.

In haar artikel Jesus en vroue (Dreyer 1999b) toon sy aan hoe Jesus vroue van hierdie (gender) rolle bevry het. Binne die streng hiërargiese reinheidstruktuur van die kultuur waarin Jesus geleef het, het Jesus onkonvensioneel gepraat en opgetree. Toe Jesus verduidelik wie tot die 'koninkryk van God' behoort en die beeld van ' $n$ familie gebruik het, het Jesus 'n ander soort familie bedoel as die biologiese familie. Jesus het op nie-patriargale wyse met vrou en kinders omgegaan. Vir Yolanda (kyk Dreyer 1998a:90-91; vgl. 1999b:71) is die 'oortuiging dat enige mens, afgesien van ouderdom, geslag of herkoms, 'n direkte en anti-hiërargiese toegang tot God het en met outentisiteit in verhouding met God staan' wat sy die 'Jesus-saak' noem.
Volgens haar (kyk Dreyer 1999b:73) het die heling van mense deur Jesus neergekom op die resosialisering, dit het beteken akkommodering in die gesinslewe en toegang tot God. Die feit dat Jesus nie opgetree het volgens die reinheidsisteem van sy tyd nie, het 'n impak gehad op die lewe van vroue en ander minderes van sy samelewing. Sy is van mening dat hierdie manier van optree van Jesus ook 'n invloed behoort te hê op die lewenskwaliteit van vroue en ander minderheidsgroepe in ons lewe van vandag (Dreyer 1999b:73).

Yolanda (kyk Dreyer 1999b:77) gebruik 'n betrokke hermeneutiek en kommunikatiewe handelingsteorie om aan te toon dat hedendaagse lesers van die $\mathrm{Ou}$ en Nuwe Testament nie bloot 'n vorige boodskap kan intolk in die hede nie, dit geld ook vir die oordrag van kultuurmaatreëls .

Jesus het gelewe binne 'n patriargale sosiale sisteem waar die vader die hoof van die familie was. Sy (Dreyer 1999b:81) toon aan hoe Jesus afwyk van die patriargale sisteem wanneer Jesus nie die verwagte rol van die oudste seun en later dié van patriarg in sy eie familie vervul nie. Vir Jesus was nie die familiehoof nie, maar God die Vader, in wie gelowiges ingebed is.

Binne die patriargale familiesisteem was die vrou 'n randfiguur, wat in die samelewing en familie nie gesien en ook nie gehoor word nie. Die status wat aan 'n vrou toegeken is, kan beskryf word as die van 'n semi-slaaf (Dreyer 1999b:82) In Jesus se omkeer van hierdie patriargale sisteem tree hy nie op soos 'n man sou optree volgens die patriargale sisteem nie. Jesus se optrede en gedrag is eerder die optrede en gedrag wat van 'n vrou verwag word (Dreyer 1999b:84).

Yolanda vestig die aandag die aandag daarop dat Jesus nie net die rol van vroue in die samelewing vertolk en so die waarde wat aan vroue toegeken is, verander het nie. Jesus het ook die beeld van God en die beeld van die vader van die familie verander. Die gelykenis van die verlore seun is vir haar 'n voorbeeld hiervan (kyk Dreyer 1999b:87-88).

Wanneer Yolanda (Dreyer 1999b) stel:

Die kultuur en sosiale sisteem waarbinne iemand leef, word gewoonlik nie bewustelik geleef nie. Onbewustelik bepaal dit egter die persoon se beskouing van die werklikheid. Dit bring mee dat mense wat binne ' $n$ kultuur leef, die waardes van die kultuur nie maklik bevraagteken nie, maar dit gewoon aanvaar as hoe dit moet wees; dit is hoe dit hoort. Vir vroue beteken dit dat hulle die rolle en gedrag wat die kultuur aan hulle voorskryf, gewoonlik aanvaar as vanselfsprekend, korrek en soos dit hoort. (bl. 89)

Dit is ' $n$ beskrywing van wat sy in ' $n$ later werk (kyk Dreyer 2006) beskryf as hoe 'n sosiale sisteem op 'n hegemoniese wyse die samelewing se optrede bepaal. Dit is volgens my deel van haar proses van bewusmaking waarin sy ook taal en woorde gee aan dit wat vroue ervaar.

\section{Vroue ervaring en spiritualiteit}

In hierdie artikel toon Yolanda aan hoe identiteit gevorm word deur internalisering en identifikasie (Dreyer 1999c). Vroue se 
identiteit word gevorm deur die gender rolle wat vroue geïnternaliseer het, en ook die persone wat deur die samelewing as voorbeelde vir vroue aangebied word om mee te identifiseer.

Sy bring met hierdie akademiese werk spiritualiteit, teologiese tradisie en vroue in gesprek met mekaar. Om die korrelasie tussen spiritualiteit en identiteit aan te toon, haal sy Theuns Dreyer (1998) aan:

Spiritualiteit as lewensoriëntasie is verantwoordelik vir die mens se identiteit ... Spiritualiteit as semantiese struktuurkern is daarom noodsaaklik vir die verstaan van dit wat mense se lewe sin gee. As betekeniskern van 'n mens se lewe het spiritualiteit te doen met 'n religieuse selfpersepsie. (bl. 300)

Ten opsigte van vroue en hulle spiritualiteit fokus sy (kyk Dreyer 1999c:364) op die relasie tussen spiritualiteit en vervreemding. Die vervreemding waarna hier verwys word, is dit wat vroue ervaar wanneer hulle leef in 'n kultuur wat deur mans gedefinieer is. 'Dit is vervreemding wat vroue ervaar wanneer hulle binne 'n manlik gedefinieerde, gestruktureerde en geregeerde kerklike kultuur as vrou en as gelowige probeer lewe' (Dreyer 1999c:364) Hierdie vervreemding word deur Schulenburg (1993:13) getipeer as 'patriarchaler Entfremdung'.

Van hierdie vervreemding het Yolanda self ervaring (kyk Dreyer 1999c:364). As die eerste vrou wat 'n geordende predikant geword het binne die Nederduitsch Hervormde Kerk van Afrika en ander Afrikaans-sprekende kerke, het sy haarself bevind binne 'n teologiese tradisie en kerk tradisie wat deur mans gedefinieer was. Daar was nie 'n vrou met wie sy kon identifiseer, by wie sy kon sien en leer hoe om 'n vrou te wees wat 'n predikant is nie.

Die bydrae wat sy lewer ten opsigte van die akademie en die ervaring van vroue, is dat ek en ander nie soos sy hierdie soort vervreemding hoef te beleef in 'n kerk en teologiese tradisie wat deur mans alleen gedefinieer is nie.

Sy toon hoe die kultuur en kerklike samelewingstrukture beperkende rolle aan vroue toeken en sodoende vroue se stemme onhoorbaar maak (kyk Dreyer 1999c:365-368). Die mees effektiewe manier vir haar om iets hieraan te doen, is bewusmaking deur middel van ' $\mathrm{n}$ bewuswordingsproses. Dit is ' $n$ bewuswording 'van onder af' wat die norme en strukture bevraagteken. Dit vra dat die androsentriese 'van bo' standpunt vervang word deur die view from below (Dreyer 1999c:368). Die view from below siening is die ervarings en insigte van hulle wat stilgemaak is deur die dominante strukture. Hierdie bewuswording lei tot die insig dat 'n eensydige manlike sosio-kulturele narratief onaanvaarbaar is in ' $n$ wêreld en kerk wat nie net uit mans bestaan nie. Dit vra vir die verskuiwing van 'n patriargale teologie na 'n kontekstuele teologie, waarin vroue volledig as subjekte funksioneer (Dreyer 1999c:369).

Die teologie van ' $n$ geloofsgemeenskap is ' $n$ belangrike bron waaruit die spiritualiteit en identiteit van 'n geloofsgemeenskap ontwikkel. Yolanda (Dreyer 1999c:369) maak gebruik van feministiese teologie om kritiek te lewer teen die patriargale strukture van die kerk en teologie en ook om te fokus op 'n soeke na 'n lewegewende teologie.

Sy (Dreyer 1999c:370) bring die insigte van Burton en Whiting (1961:89) ten opsigte van verskillende tipes identiteit wat onderskei kan word, onder die aandag. Die drie tipes identiteit wat melding van gemaak word, is toegekende identiteit, subjektiewe identiteit en optatiewe identiteit. Toegekende identiteit is dit wat ' $n$ ander of 'n groep oor 'n persoon sê. Subjektiewe identiteit is wat 'n persoon van hulle self dink. Optatiewe identiteit is wat'n persoon graag sou wou hê ander van haar/hom moet sê, maar wat om bepaalde redes nie gebeur nie. Yolanda (Dreyer 1999c) stel dit soos volg:

Gesien in die lig dat ' $n$ samelewing vir sigself die goeie wil bevorder, kan beweer word dat sosialisering ten doel het dat ' $n$ persoon se ideale visie vir haar- of homself sal saamval met sowel iemand se selfpersepsie as die identiteit wat aan haar of hom toegeken word. (bl. 370)

In 'n manlik-gedomineerde wêreld is hierdie saamval vir vroue nie moontlik nie. Volgens haar (Dreyer 1999c:371) is die rede hiervoor dat vanaf die vroegste geskiedenis bepaal mans hoe vroue moet wees, lyk en optree. Die Godsbeelde wat vroue se spiritualiteit vorm, word in kerk en teologie deur mans bepaal.

Ervaring toon dat toon dat vroue gesosialiseer word om te konformeer na die ondergeskikte rolle wat in die teologie aan hulle toegeken is:

Vroue is geleer om hulleself te verloën en hulle eie behoeftes en belange op te offer ter wille van ander. Waar mans geleer is om selfverloëning te sien in die konteks van profetiese moed van hulle oortuiging. (Dreyer 1999c:372)

Vroue is ook geleer dat hulle waarde nie geleë is in hulle eie identiteit nie, maar dat hulle lewe en identiteit opgaan in dié van ander. Die boodskap aan vroue was dat hulle eers waarde kry wanneer ' $n$ manlike persoon haar 'vind' en haar lewe in dié van dié man opgaan.

Yolanda se kritiek teen hierdie boodskap aan vroue bring bewuswording. Vroue het ander vroue in leiersposisies nodig om mee te identifiseer vir die vorming van hulle eie spiritualiteit en identiteit. Vir vroue is spiritualiteit om verbande te lê tussen wat hulle glo en die alledaagse ding van hulle bestaan (Dreyer 1999c:377). Dit gaan dus om spirituele heelheid in plaas van gespletenheid.

\section{Huwelik}

Yolanda se navorsing ten opsigte van die 'Vrou as beeld van God', vorm volgens my 'n belangrike onderbou in haar bydra op die akademiese gebied wat verandering gebring het in die rol en waarde wat aan vroue toegeken is in die huwelik. Sy toon ook aan hoe die patriargale huwelik ' $n$ invloed het op die spiritualiteit van vroue.

Sy toon aan dat die problematiek rakende die beskouing van die kerk oor die huwelik nie net gaan oor die rolle wat aan vroue toegeken is nie, maar ook oor die plek en status wat die 
kerk en samelewing aan die huwelik as instelling toeken. Wat volg is ' $n$ waarderende refleksie van haar bydrae ten opsigte van die genoemde sake.

In twee van haar artikels getiteld: Vrou as beeld van God: 'n Historiese ondersoek - Vanaf Genesis tot die Middeleeue (Dreyer 2000a:672-696) en Vrou as beeld van God: Vanaf die Reformasie tot die twintigste eeu (Dreyer 2000b:949-972), toon sy hoe daar gedink is oor die waarde van vroue op grond van die uitleg van die Genesis 1:27 teks: 'God het die mens geskep as God se verteenwoordiger, as beeld van God het God die mens geskep, man en vrou het God hulle geskep' (NAV).

Yolanda bespreek hoe die Bybel en Bybeltekste gebruik is om die heersende antropologie te legitimeer en 'aan te dui hoe die status quo 'n skeppinsordening van God is' (kyk Dreyer 2000a:673). Die konstruksie van genderverskille in die Christelike tradisie voer sy terug na die filosofiese sisteme van die Platonisme, Neoplatonisme en Aristotelianisme wat in die Bybel ingelees is.

Sy toon gevolglik aan dat die tradisies in die Pentateug, veralwatdieskeppingstradisies betref, diegelykwaardigheid van man en vrou as beeld van God impliseer (Dreyer 2000a:673). In die Priesterlike tradisie word die verskil tussen die geslagte as 'n biologiese aangeleentheid gesien. Die Jawistiese tradisie vul die Priesterskrywers aan deur ook te fokus op sosiale aspekte soos kameraadskap (kyk Dreyer 2000a:674). Sy wys uit hoe hierdie aangewesenheid op mekaar juis binne die patriargale konteks van die tyd die deur open dat vroue uitgebuit kan word. 'n Voorbeeld van hierdie uitbuiting is vir haar (kyk Dreyer 2000a:675) die sisteem van 'Patrilokale residensie', waar vroue uit die huishouding van hulle vader geneem is en ingeneem is in die huis van hulle man. Vroue wat so in die huishouding van die man opgeneem is, is eers as deel van die gemeenskap gereken wanneer hulle die familie van 'n manlike erfgenaam voorsien het.

Hoewel die asimmetrie, ongelykheid tussen man en vrou, in die patriargale gemeenskap waarskynlik nie deur Genesis 1:27 betuig word nie, sien mens binne die patriargale samelewing hoe die lot van vroue onlosmaaklik verbind was aan die van 'n man (pa of eggenoot). Die meerderwaardige posisie wat aan mans toegeken is bo die afhanklike minderwaardige posisie van vroue is verbind aan die patriargale Godsbeeld (kyk Dreyer 2000a:679-680). Wat aanleiding gegee het tot die 'afskeep' van die Genesis 1 teks is die feit daar in die Christelike tradisie meer klem gelê is op die tweede skeppingsverhaal en dit die teks geword het van waaruit Genesis 1:27 geïnterpreteer is (Dreyer 2000a:678; vgl. Gössmann 1996:199).

Die implikasies hiervan kan duidelik in inter-testamentêre tekste gesien word. Yolanda toon aan dat veral Filo se siening dat die hiërargie tussen die geslagte 'n skeppingordening is, die Christelike tradisie oor die posisie van die vrou teenoor die man sterk beïnvloed het (kyk Dreyer 2000a:683-685). So meen Origenes dat geslagtelike differensiasie (en daarom hiërargiese ordening) eers by die eskatologiese einde opgehef sal word (kyk Dreyer 2000a:686).

Sy (Dreyer 2000a:687) vermeld dat wat die patristiese literatuur betref die vooronderstelling gehuldig is 'dat Eva met haar sonde haarself vervreem het van die moontlikheid om "beeld van God" te wees'. So ontwikkel die beeld van vroue as persone met 'n God-vervreemde ondergeskiktheid (kyk Dreyer 2007b:1503-1511).

In die Middeleeue bevestig Thomas van Aquinas dat vroue geskape is na die beeld van God, maar beklemtoon steeds die voorrang van die man. Vroue is beskou as fisiek minderwaardig aan mans en daarom is hulle ook ondergeskik aan mans. Die man-vrou hiërargie is volgens hom deel van die skeppingsorde (kyk Dreyer 2000a:692).

In terme van die ondersoek na 'Vrou as beeld van God' in die tydperk na die Reformasie tot die twintigste eeu bevind Yolanda die volgende:

Gedurende die Renaissance vind daar vanaf die Aristoteliese denke dat vroue niks anders is as 'gebreklik mans' nie, 'n verskuiwing plaas na die siening dat die vroulike geslag sigself normaal en natuurlik is. Daar is egter steeds geoordeel dat die vroulike geslag swakker en meer broos is as die manlike en daarom beskerm moet word ... (Dreyer 2000b:949)

Nog 'n verskuiwing ten opsigte van die denke oor vroue wat sy (Dreyer 2000b:949) vermeld is die Aristoteliese siening dat die fetus die gevolg was van alleenlik die man se saad na die siening dat vroue ook 'n bydrae daartoe lewer. Die vraag oor die natuur van vroue was steeds relevant in die tyd van die hervormers. Ek vermeld kortliks haar (kyk Dreyer 2000b:951969) nadenke ten opsigte van wat hervormers soos. Luther en Calvyn oor vroue gesê het, sowel wat gesê is oor die natuur van vroue tydens die Verligting, die Romantiek en PostAufklärung en dan ook die feministiese beweging se bydrae tot die saak.

Hoewel Luther die siening van Aristoteles, naamlik dat vroue gebreklike mans is verwerp, beskou Luther in sy kommentaar op Genesis 1:27 die vrou steeds as minderwaardig teenoor die man. Eva word gesien as die swakker deel van die menslike natuur (Dreyer 2000b:951952; kyk 2007b:1529-1530). Calvyn se posisie ten opsigte van vroue is dat hulle gebore is om te gehoorsaam. Sy verwys soos volg oor Calvyn se siening van die posisie van vroue:

Hoewel Calvyn dus nie die tradisionele argument van vroue se minderwaardige natuur wil volg nie, kom sy oordeel op die ou end maar weer neer op die minagting van vroue se natuur. Daarby beroep Calvyn hom op die vanselfsprekendheid van algemene kennis en stemming van die saak. (Dreyer 2000b:954)

Vroue is vir Calvyn ook na die beeld van God geskep, maar slegs in die tweede graad. Die man is verantwoordelik vir die vrou en sy is ondergeskik aan die man. Ten spyte van hierdie siening van Calvyn oor die plek van die vrou, sien hy die vrou in die huwelik as lewenslange kameraad (Dreyer 2000b:955, 2007b:1531-1532). 
Ten opsigte van die verligting word die volgende vermeld:

Die patriargale idee van manlike hoof van die familie as verteenwoordigend van die mensheid en van sy gesin is dus, ten spyte van grootliks veranderde denke voortgesit. Die verligtingsdenke het egter wel die klimaat verskaf waarbinne die feminisme begin werk het om vroue as outonome persone ingesluit te kry by burgerregte. (Dreyer 2000b:956; kyk 2007b:1533-1541)

Hier is dit ook nodig om aandag te gee aan Yolanda (kyk Dreyer 2007a; 2007b) se navorsing op die werk van Karl Barth en in besonder sy teo-etiek, Barth se teologiese model wat gebaseer is op 'Christian revelation' en hoe Barth dit ingespan het in sy verstaan van Genesis 1:27 en dit toegepas is om die rol en plek van vroue binne die samelewing en huwelik te bepaal. Sy (Dreyer 2007a:1493) beskryf Karl Bath se manvrou-orde as a-simmetriese teo-etiek. Sy toon aan dat Barth se 'theology of revelation from above' in Jesus Christus - sy Christus-sentriese hermeneutiek gevorm en beïnvloed is deur die patriargale Christelike tradisie (kyk Dreyer 2007a:1493-1494). Sy (Dreyer 2007a) stel:

Though Barth describes his view as 'theological', it clearly represents male bias, human prejudice and his entrapment within patriarchal Christian tradition. Barth's model based on the 'Christ revelation', is consistently applied in such a way that it objectifies people. (p. 1496)

In die premoderne, patriargale sosiale konteks van die vroeë Christene, was die onderdanigheid van getroude vroue aan hulle mans 'n gegewenheid. Hierdie sosiale verskynsel is deur Christene gemistifiseer en gelegitimeer deur gebruik te maak van godsdiens. Een van die Bybelse konsepte wat gebruik is vir hierdie doel in die vroeë Christendom en ook deur Karl Barth in sy teologie is die konsep; beeld van God (the image of God) (kyk Dreyer 2007a:1497). Die manlike hoof van die huishouding het 'die beeld van God' weerspieël, en het daarom outoriteit gehad oor al sy besittings, dit het ingesluit, sy vroue, kinders en slawe. Volgens Barth is die onderdanigheid van vroue teenoor mans deur God verorden tydens die skepping en is daarom 'n onveranderlike gegewe (Dreyer 2007a:1498).

Yolanda (kyk Dreyer 2007a:1501) maak gebruik van 'n hermeneutiek van suspisie om kultuurkrities na die werk van Barth te kyk. Sy toon aan dat Barth se teologiese etiek gebaseer is op 'covenantal creational theology'. Wanneer daar kultuurkrities gekyk word na Barth se teologie word dit duidelik dat Barth dit nie reggekry het om homself los te maak van die patriargale onderdanigheid van die vrou nie. Dit word duidelik wanneer uit dit wat Barth oor die huwelik sê, naamlik dat dit onder een van die skeppingsordinansie ressorteer (Dreyer 2007a:1501). Sy (kyk Dreyer 2007a:15121513) toon aan dat Barth meen dat die verskil tussen man en vrou nie noodwendig in hulle natuur of essensie is nie, maar in hulle funksie.

Sy (Dreyer 2007a:1515) wys daarop dat Barth Efesiërs 5:22-23 as die Locus Classicus vir die verhouding tussen man en vrou beskou. In die teks word die verhouding tussen man en vrou direk in verband gebring met die verhouding tussen Christus en die geloofsgemeenskap, op grond hiervan meen Barth dat die teks die onderdanigheid van vrou bevestig en beklemtoon.

In haar artikel: Bybelse huweliksrolle en die moderne egalitêre huwelik (Efesiërs 5:21-32) toon Yolanda (kyk Dreyer 1996:95103) deur gebruik te maak van kennis uit die sosiaal wetenskappe wat dit moontlik maak om die teks kultuurkrities te lees, dat dit nie die kernboodskap van die teks is nie. Sy (Dreyer 1996:97) wys daarop dat die opdrag wat in verse $25-30$ aan die man gegee is, radikaal is. In Haustafeln (Kodes wat opgestel is vir huishoudelik gedrag) is daar nie aan die man voorgeskryf nie. In die genoemde verse word die man beveel om sy vrou lief te hê. Die liefde van die man vir sy vrou is gebaseer op Christus se selfopofferende liefde vir die kerk. Daar word nuwe inhoud gegee aan die konsepte van 'hoofskap' en 'onderdanigheid' (kyk Dreyer 1996:98-100). Hoofskap beteken nou nie meer een persoon se dominansie oor die ander nie, maar word Christologies verstaan as dien, prysgawe van die self en liefde. Die onderdanigheid van vroue word verstaan as respek. Dieselfde prysgawe wat van vroue verwag word, word nou ook van die mans verwag (Dreyer 1996:102).

Die alternatief wat sy bied vir hoe daar tradisioneel oor vroue as beeld van God gedink is, die rol wat vroue inneem teenoor mans, is ' $n$ feministiese alternatief, ' $n$ feministies hermeneutiek:

In die moderne feministiese hermeneutiek slaan die bespreking oor die mens, man en vrou, as beeld van God 'n ander rigting in. In die eerste plek word aanvaar dat alle Godsbeelde wat mense konstrueer, gewoon menslike projeksies is ... Enige poging om God te verbeeld moet dus geskied met groot omsigtigheid, nederigheid en erkenning van die beperkings en die voorloopigheid van só 'n poging. (Dreyer 2000b:965)

Die feministiese hermeneutiek wend 'n poging aan om man en vrou te rekonstrueer as gelyke draers van God se beeld. Images of God that are constructed, should provide space for the full realization of Human potential for women and men (Dreyer 2007b:1543). Daar behoort gevra te word na menslike voorstellings van God wat daartoe aanleiding gee dat vroue nie as volwaardige mense, outentiek voor God, in die samelewing kan leef nie. Daar behoort fyn geluister te word na die stemme wat deur die dominante narratief (patriargie) stilgemaak is, om sodoende aanpassing te maak en vernuwing te bewerk (kyk Dreyer 1999a:61).

Die bydrae wat Yolanda lewer is nie net die fokus op die minderwaardige rolle wat aan vroue binne die huwelik toegeken is nie, maar ook op die plek en status wat aan die huwelik deur die kerk in die samelewing toegeken word. Vervolgens ' $n$ blik op haar bydrae in hierdie verband.

In haar artikel, "The "sanctity" of marriage - an archeology of as socio-religious construct: Mythological origins, forms and models' (Dreyer 2008a:499-527) tree Yolanda in gesprek met C.R. Roberts (2007) se siening oor die huwelik soos gestel in sy boek: Creation and covenant: The significance of sexual difference 
in the moral theology of marriage. Roberts is van mening dat die fokus op seksuele verskille tussen man en vrou belangrik is vir die ontwikkeling van 'n 'moral theology' van die huwelik (kyk Dreyer 2008a:500-503). Sy verwoord Roberts se siening soos volg:

In his view, the creation of man and woman forms part of the order of creation. This would mean that sexual difference is of the utmost importance when theologising about marriage. Roberts, building on Karl Barth, who, in turn, builds on Luther, does not see marriage as sacrament. However, both Luther and Barth regard marriage as part of the order of creation ... Sexual difference is therefore important to Luther and Calvin, as well as to Barth and Roberts when they discuss marriage from a theological perspective. (Dreyer 2008a:500; kyk 2007a:1493-1521; 2007b:1523-1547)

Yolanda toon aan dat seksuele verskille tussen man en vrou as soteriologies onbelangrik beskou behoort te word (Dreyer 2008a:521-522). Hoewel seksualiteit deel is van die realiteit van menswees, word dit beïnvloed deur sosiale konstrukte en die huwelik, wat ook 'n sosiale konstruk is. Sy neem die biologiese en sosiale aspekte in ag wanneer sy 'n teologiese benadering volg wat aan die een kant geïnteresseerd is in die verhouding tussen God en mense en aan die ander kant geïnteresseerd is in hoe die Bybel seksualiteit en die huwelik verstaan. Sy toon aan dat die idee dat geslagsgemeenskap tussen man en vrou gelyk is aan 'n Godgegewe 'heilige huwelik' (holy matrimony) 'n mitologiese oorsprong het (Dreyer 2008a:502; 2011:4). Yolanda bespreek hierdie mitologiese oorspronge (kyk Dreyer 2008a:505-507) en die verskillende huweliksvorme en huweliksooreenkomste wat bestaan (kyk Dreyer 2008a:507-521; 2011:3-4).

Yolanda wys daarop dat hoewel die huwelik binne die Protestantse teologie nie meer as sakrament beskou word nie, dit steeds die huwelik beskou as the institution of marriage as a reflection of the kingdom of God. 'Holy matrimony' remains a God-given heterosexual ordinance where the difference between maleness and femaleness essential is (Dreyer 2008a:502). Sy lewer kritiek teen die essensialisme wat onderliggend is aan die beklemtoning van seksuele verskille in die huweliksteologie. Dit is volgens haar begrond op 'n dualistiese antropologie. Sy maak gebruik van Rosemary Radford Ruether (1975; 1983; 1991) se feministiese kritiek op dualistiese antropologie (Dreyer 2008a:521). Sy haal Coll (1994:70) aan om aan te toon wat die verskil tussen dualistiese antropologie en:

'[S]ingle-nature theory' is: Dual-nature anthropology suggests that women and men are different nature determined by God and that these different natures determine what is appropriate for each sex ... [S]ingle-nature theory ... holds that most differences between women and men are culturally defined and therefore open to change. (Dreyer 2008a:521)

Vir haar is die bewusmaking daarvan dat sosiale konstrukte soos die huwelik menslike instellings is en nie God-gegewe is nie belangrik vir die outentieke lewe van mense. Sy toon aan dat wanneer die patriargale heteroseksuele huwelik verabsoluteer word dit 'n hegemonie word (kyk Dreyer 2008a:522).
In haar artikel: 'De-centre-ing' sexual difference in public and ecclesial discourses on marriage (2008b:715-765) word aangetoon dat die heteroseksuele verskil tussen manlik en vroulik sowel as monogame lojaliteit sentraal gestaan het binne die kerk se verstaan van die huwelik (kyk Dreyer 2008b:715-716). Yolanda argumenteer met hierdie artikel:

against religious, naturalistic and heterosexual essentialism with its emphasis on the biological sexual difference between maleness and femaleness ... [sy kies vir] a 'de-centre-ing' of the sexual difference of maleness and femaleness, which will provide a different kind of language for articulating the relationship between people among themselves and between God and human beings. (Dreyer 2008b:716)

Hierdie ander manier van praat oor mense se verhoudings met mekaar en met God noem sy Relational 'Bible-talk' (kyk Dreyer 2008b:729-731). Met hierdie artikel ontmasker sy die skade en geweld wat mense aangedoen word deur die kerklike en publieke diskoers oor die huwelik en seksualiteit. Sy toon ook aan hoe positivistiese benadering tot die Bybel gebruik word om sosio-religieuse essensialisme te legitimeer (kyk Dreyer 2008b:725).

Yolanda (kyk Dreyer 2008b) bespreek in hierdie artikel ook die drie postmoderne benaderings tot die huwelik wat Roberts (2007) in sy bogenoemde boek, wat handel oor sy teologie van die huwelik, verwerp het. Die drie benaderings is: die huwelik as linguistiese uitdrukking van intimiteit, die huwelik geldend vir nie-heteroseksueles, die huwelik ingebed in die gemeenskap (kyk Dreyer 2008b:719-726). Die eerste benadering is dié van Graham Ward (1998). Vir Ward $(1998: 52,54,55,63)$ is die betekenis van seksuele verskille geleë in die taal wat dit verskaf om teologies te praat oor 'intimacy, distance, relationship and separation, as well as otherness' (Dreyer 2008b:719). Die tweede benadering is dié van Eugene Rogers (2004). Rogers (2004:29) vind nie die betekenis van seksuele verskille in imago Dei soos Barth nie. Rogers verwerp die idee dat die verskillende geslagte mekaar komplimenteer en saam die 'wholeness of humanity' vorm (Dreyer 2008b:721). Die derde benadering is dié van David Matszko McCarthy $(2001 ; 2002)$ wat fokus op die konteks waarbinne 'n huwelik plaasvind, dit gaan nie net oor die twee mense wat in die huwelik tree nie, maar ook oor die invloed wat dit het op die geloofsgemeenskap waarbinne hulle leef (kyk Dreyer 2008b:722-723).

Ek gaan voorts aandag gee aan die bydrae wat Yolanda (kyk Dreyer 2008b:729-735) met wat sy noem 'Relational Bible talk' of analogia relationis:

An analogia relationis (the consequences of which neither Barth nor Roberts succeed in fully working out) would open up a radically new perspective on sexuality, intimacy and marriage, where these three aspects are not connected directly to God's act of creation. God could then be seen as being in a dynamic relationship with human beings, the nature of which (namely love) would be determinative of human interaction, including sexuality, intimacy and marriage. All (not only those based on sexual difference) intimate relationships between human beings could then refer back to God's relationship with human beings. (Dreyer 2008b:730) 
Verhouding wat gebaseer is op analogia relationis beklemtoon vir haar die 'relatedness' van mense eerder as die 'sameness'. Hierdie 'relational thinking' veronderstel vir Yolanda die 'desacramentalizing' van die huwelik as 'n God-gegewe instelling en 'de-centre-ing sexual difference' (kyk Dreyer 2008b:731-733).

\section{Seksualiteit}

Yolanda se akademiese bydrae ten opsigte van navorsing oor seksualiteit en hoe seksualiteit in die kerk geïnterpreteer is, strek wyer as dit wat sy oor die huwelik en gender geskryf het. Die verstaan van seksualiteit en die manier waarop dit toegepas word deur die kerk en samelewing bepaal ook hoe daar oor homoseksualiteit gedink word. Haar bydrae op die gebied van seksualiteit is baie nou verbind met die insigte wat sy lewer in haar navorsing oor homoseksualiteit. Hoe daar oor seksualiteit gedink word, het 'n invloed op denke oor homoseksualiteit en heteroseksualiteit.

Sy (Dreyer 2005:729) toon aan dat die huwelik, seksualiteit en godsdiens aan mekaar verbind is. Dit is waar in die premoderne Mediterreense wêreld en ook in ons wêreld van vandag:

In the premodern Mediterranean world sexuality, religion and marriage were tightly woven together in the social fabric. The source book of Christianity, the Bible, is a document which originated in this world. Its perspectives on sexuality, religion and marriage are premodern. What was understood by these three concepts then differs from the understanding of the Modern Era. Today, evidence points to a radical shift yet again from the Modern to the Postmodern Era. (Dreyer 2005:729)

Die Bybel as brondokument van die Christelike geloof word dikwels gebruik om bestaande idees oor seksualiteit, gender en homoseksualiteit in stand te hou. Wanneer die kerk (godsdiens) en kultuur uitsprake maak ten opsigte van seksualiteit het dit dikwels ten doel om mense se seksualiteit in te perk en te beheer (kyk Dreyer 2006; 2007c; 2008b:727-728).

Yolanda (Dreyer 2005:729-730) beskryf die manier waarop die reëls waarvolgens opgetree en geleef word en in 'n samelewing geïnternaliseer word, as 'n proses van sosialisering. Reëls en norme wat deur die proses van sosialisering geïnternaliseer is, word nie maklik verander nie. Hierdie reëls en waardes word dikwels gebruik om die magsbalans in die samelewing te handhaaf. Reëls en waardes wat magsposisies se belange in stand hou of beskerm, verander baie stadig. Voorbeelde van verandering wat stadig plaasvind is byvoorbeeld die verskuiwing vanaf aristokrasie na demokrasie, die verandering in eer en skaamte kodes. Binne die premoderne Mediterreense wêreld sowel as die Moderne Era was gender en seksualiteit ingebed in die eer en skaamte kodes; daarom vind verandering op hierdie gebiede stadig plaas:

Only when socialised norms have changed, will it be possible to recognize that inherited (from the premodern Bible and the Modern Era) perspectives on gender and sexuality are at odds with today's world. (Dreyer 2005:730)
Die uitdaging waarvoor die kerk gestel word, is om die veranderings in die sosiale onderlinge verbinding (interconnectivity) tussen seksualiteit, godsdiens en die huwelik, asook die waardes wat daarmee saamhang, te erken. Sy beskou die onderlinge verbinding tussen seksualiteit, godsdiens en die huwelik as deel van die prosesse van institusionalisering en de-institusionalisering (kyk Dreyer 2002:625-641; 2005:731).

Yolanda (Dreyer 2005:732) is dit eens met Paul Tillich (1957:14-18) dat die vrae wat deur die kultuur gevra is, die inhoud van die teologiese antwoorde bepaal het. Saam met Nelson (1992:115-116) tref sy 'n onderskeid tussen seksuele teologie en teologie van seksualiteit (Dreyer 2006:454). Adrian Thatcher (1999) verduidelik die verskil tussen bogenoemde soos volg:

The latter concerns itself with the Bible and tradition as these deal with sexual questions. These findings are then applied to contemporary sexual dilemmas and problems. But sexual theology begins with our experience as embodied, sexual beings. (p. 21)

In haar bespreking van seksualiteit, gee sy aandag aan hoe daar omgegaan is met seksualiteit binne die sosiale wêreld van eerste-eeuse Oos-(Semitiese) Mediterreense wêreld, en die Wes-Mediterreens (Grieks-Romeinse) sosiale wêreld (kyk Dreyer 2005:733-742; 2006:455). Sy belig ook die Moderne en Postmoderne sienings ten opsigte van seksualiteit (kyk Dreyer 2005:742-743).

Die sosiale wêreld van eerste-eeuse Oos-(Semitiese) Mediterreense wêreld was patriargaal, die vader is gesien as die verteenwoordiger van God. Gender-rolle is toegeken kragtens die eer en skaamte kodes. Manlike eer was geleë in die testikels. Vroulike eer is gesimboliseer deur die maagdevlies. 'n Vrou se seksuele reinheid was hoofsaak vir haar man en manlike kinders. Israel was 'n tempelstaat, policies were determined by the purity ideology of the Jerusalem temple cult - an ideology that marks Israelite society as patriarchal, exclusivist and hierarchical (Dreyer 2005:735). Seksualiteit en huweliksregulasies was vasgestel deur die tempel en reëls oor aanvaarbare, toegelate seksuele relasies was afgelei uit die Tora. Seksuele gedrag het binne die reinheidsideologie geval. Seksuele omgang met dieselfde geslag is veroordeel as ' $n$ onrein daad. Binne 'n patriargale samelewing bedreig homoseksuele gedrag die noodsaaklike voortbring van manlike erfgename (Dreyer 2004:184; vgl. Melcher 1996:93-99).

Binne die patriargale huwelikstruktuur het daar drie tipes huwelikstrategieë bestaan wat die samelewingsbelange gedien het (Dreyer 2006:455; kyk 2005:736-737). Binne die patriargale samelewing is daar verwag dat manlike seksualiteit aktief en aggressief moet wees, omdat dit 'n simbool is van manlike eer. Hierteenoor moet vroulike seksualiteit beheer word omdat dit 'n bedreiging inhou om die manlike publieke orde te versteur. Manlike seksualiteit word binne die patriargale konteks verstaan as mag oor ander (kyk Botha \& Dreyer 2007:1249). 
In die Grieks-Romeinse wêreld was seksuele omgang tussen persone van dieselfde geslag nie ongewoon nie. Seksuele omgang met vroue was nodig vir prokreasie, maar in die Grieks-Romeinse kultuur is verhoudings tussen mans gesien as die 'hoogste vorm van liefde' (Dreyer 2006:455; kyk 2005:738).

Die Grieks-Romeinse samelewing was gedryf deur kompetisie vir mag en dominansie. Seksuele aktiwiteite was 'n refleksie hiervan (Dreyer 2005:738; vgl. Winkler 1990:4570). Die fokus het in hierdie kultuur geval op die passiwiteit of aktiwiteit van die deelnemers. Om passief te wees in die seksdaad het beteken dat 'n persoon hom/haar ondergeskik stel aan die gesag van die ander. Dit was dan ook die rede waarom mans ander mans verkrag het (Dreyer 2006:455; vgl. Allen 2000:214-215). Yolanda (Dreyer 2006:455) haal Garton (2004) aan om hierdie punt te illustreer:

Enforcing sexual submission or humiliation was a means of asserting dominance ... Thus there were very specific sanctions against sex between male citizens of the same status because these threatened codes of masculine dominance. (p. 33)

Die oortreding van geslagsrolle was die grootse probleem van die antieke tyd. Op grond van hierdie insigte is Yolanda (Dreyer 2006:456) se bydrae dat seksuele identiteit 'n kulturele eerder as 'n natuurlike of essensiële kategorie is.

Yolanda (Dreyer 2005:742; kyk 2006:456) is van mening dat hoe seksualiteit vandag verstaan word gevorm is deur moderne denke, dit sluit in die insigte van Freud (1938) en ander:

Die moderne siening van seksualiteit was 'essensialisties', met ander woorde man-wees en vrou-wees bevat sekere wesenskenmerke wat in alle kulture en oor alle tye heen by alle mans en vroue aangetref word. (Dreyer 2006:456)

Hierteenoor is die postmoderne benadering tot seksualiteit anti-essesialisties. Hierdie benadering berus op die siening dat seksuele identiteit nie 'n wesenlike saak is nie, maar sosiaal gekonstrueer word (Dreyer 2005:742-743). Sy bring die insigte van die postmoderne filosoof Michel Foucault ([1976] 1978), ten opsigte van seksualiteit, onder die aandag. Foucault (1988:77) verwerp die moontlikheid van 'n a-historiese waarheid oor seksualiteit en wys op die ingewikkelde mag/kennis meganismes onderliggend aan diskoerse oor seksualiteit. Seksualiteit word dikwels gebruik op terreine wat op die oog af niks met seks te doen het nie om spesifieke groepe te stereotipeer en hulle minderwaardigheid aan te toon (vlg. Dreyer 2006:456).

Yolanda (Dreyer 2004:180) toon aan hoe die maniere waarop daar met die Skrif omgegaan word en tekste gebruik word om oor seksualiteit, gender en die huwelik te praat, bepaal hoe daar oor seksualiteit gedink word. Sy onderskei tussen drie eksegetiese benaderings wat gevolg word wanneer daar oor seksuele gedrag en spesifiek homoseksualiteit, uitsprake gemaak wil word vanuit die Skrif. Die drie benaderings is objektiewe Skrifverstaan, subjektiewe Skrifverstaan en dialektiese Skrifverstaan (kyk Dreyer 2004:181-183). Volgens die objektiewe benadering tot die Bybel laat die geopenbaarde wil van God net twee moontlikhede toe waarop seksualiteit uitgeleef mag word, die heteroseksuele huwelik of selibaat buite die huwelik. Vir hierdie benadering is wetenskaplikeempiriese gegewens van minder belang in Christelike etiese nadenke. Homoseksuele praktyke word as immoreel beskou, selfs al toon wetenskaplike navorsing dat homoseksualiteit algemeen is, geneties veroorsaak word en nie verband hou met psigiese probleme nie (Dreyer 2004:181-182).

Die subjektiewe eksegetiese benadering tot die Bybel fokus op 'n nie-letterlike verstaan van die Bybel en die Bybelse kulture kan nie net so toegepas word op vandag se lewe nie. Volgens hierdie benadering is die Nuwe-Testamentiese gedeeltes wat handel oor homoseksuele gedrag nie onversoenbaar met die Skrif nie (kyk Dreyer 2004:183).

Die derde eksegetiese benadering is 'n dialektiese benadering, hier word die hermeneutiese boog van Ricoeur ([1986] 1991) gebruik. Volgens hierdie benadering is daar wanneer tekste geinterpreteer word twee kontekste ter sprake, eerstens die literêre en sosio-historiese konteks van die teks en tweedens, die kulturele konteks van die eksegeet, dit sluit in die persoon se voorverstaan, vooronderstelling en sosiale milieu (Dreyer 2004:183; vgl. Via 2003:2-3):

'n Ander belangrike beginsel vir die interpretasie van die Bybel is dat die kanon ' $n$ ryk en diverse - soms teensprekende - horison bied waarteen individuele tekste verstaan behoort te word. Tekste het verskillende betekenisse in verskillende kontekste. (Dreyer 2004:184)

Volgens hierdie benadering bied die Ou-Testamentiese getuienisniegrondevir'nChristelikeetiek wathomoseksualiteit veroordeel nie. 'Homoseksuele' gedrag in die Ou Testament is kultureel bepaal. Die etiek van Ou-Testamentiese Israel is in 'n sekere sin " $n$ etiek van genitalië' (Dreyer 2004:184). Ten opsigte van die Nuwe Testament word daar'n keuse gedoen vir Paulus en Jesus se hantering van die reinheidskodes van die $\mathrm{Ou}$ Testament (kyk Dreyer 2004:185-187):

Vanuit 'n dialekties-teologiese perspektief is dit nie nodig om skrif-uitsprake oor 'homoseksualiteit' as negatief te sien nie. Kultuur-bepaalde uitsprake in die Ou Testament is 'hervorm' deur die evangelie van Jesus Christus soos veral die Nuwe Testament daaroor getuig. Volgens die evangelie is mens-wees as sodanig (sarkikos-bestaan) nie sondig nie. Sonde is om die heil te soek in mens-wees in plaas van God. (Dreyer 2004:199)

Yolanda (Dreyer 2004:176) bring die belangrike feit onder die aandag dat die term 'homoseksualiteit' vreemd is aan die Bybelse taalgebruik. Dit kom nêrens in die Bybel of die wêreld van die Bybel voor nie. Die term homoseksueel is in 1892 uit die Duits in Engels oorgeneem. Sy bring die volgende perspektief:

Gemarginaliseerde mense was welkom in die vroeë Christelike gemeenskap. In die gemeenskap was almal gelyk, liefde was die norm en sorg vir mekaar is beskou as belangrik ... Die insluiting van randfigure wys dat God se liefde groter en anders is as dié van mense wat net voorwaardelik kan liefhê en diegene uitsluit wat volgens konvensie en kultuur as onaanvaarbaar gereken word. (Dreyer 2004:199-200) 
Yolanda (kyk Dreyer 2006:446; 2007c:1-18) lewer die belangrike bydra om aan te toon dat die oortuiging, dat heteroseksualiteit die enigste aanvaarbare seksuele oriëntasie is, wat deur kerk en kultuur op grond van 'n bepaalde manier van Skrifverstaan (objektiewe Skrifverstaan) en vooronderstellings en vooroordele oorgedra is, aanleiding gegee het tot heteroseksisme en homofobiese gedrag teen mense wat 'n homoseksuele seksuele oriëntasie het (kyk Dreyer 2008c:1235-1254). Ten einde die moontlikheid te ontsluit vir die kerk om lidmate pastoraal te begelei ook ten opsigte van hulle seksualiteit, is die volgende vir haar belangrik:

Distorted ideas of sexuality in the church should first be healed before the church can heal people who have been wounded in their sexual humanness, in their most vulnerable humanity. To do so, the church wil have to let go of power and control (see Kennedy 2001:183) in order to be restored in its authentic authority - an authority that does not want to control by abusing and humiliating others, but that wants them to grow to their fullest Human potential and to be the healthy beings that they were created to be. In order to heal the alienation within Christianity, the institutional church should be pastoral in its approach to a broken humanity, attempting to heal the wound in Human sexuality that has so often exacerbated ... (Dreyer 2008c:1251)

\section{Slot opmerkings}

Dit is my oortuiging dat die bydraes wat Yolanda gelewer het en steeds lewer ten opsigte van die diskoerse van die huwelik, gender en seksualiteit, tydloos is. Dit is tydloos omdat die bewuswording van 'n mens se eie sosialisering, die rolle wat aan mense toegeken word in die samelewing op grond van hulle geslag, seksualiteit en huwelikstatus, steeds vandag die sake ter tafel is. Haar bydrae bied 'n roetekaart, wat die slaggate van gender-rolle, die hetero-normatiewe huwelik en die essensialitiese manier waarop daar oor seksuele oriëntasie gedink word, aantoon. Haar benadering is pastoraal, met as doel en eindpunt die moontlikheid vir mense om outentiek, heel voor God te leef. Dit bly 'n proses van bewuswording, die reis duur voort.

\section{Erkenning \\ Mededingende belange}

Die outeur verklaar dat sy geen finansiële of persoonlike verbintenis het met enige party wat haar nadelig kon beïnloed het in die skryf van hierdie artikel nie.

\section{Literatuurverwysings}

Allen, D., 2000, The world of Prometheus: The politics of punishment in democratic Athens, Princeton University Press, Princeton, NJ.

Bonhoeffer, D., 1967, Letters and papers from prison, SCM, London.

Botha, A. \& Dreyer, Y., 2007, 'Demistifikasie van die metafoor "die kerk as bruid"', HTS Theological Studies 63(3), 1239-1274. https://doi.org/10.4102/hts.v63i3.251

Buber, M., [1953] 1988, Eclipse of God. Studies in the revelation between religion and philosophy, Humanities Press International, Atlantic Highlands, NJ.

Burton, R.V. \& Whiting, J.W.M., 1961, 'The absent father and cross-sex identity', MerillPalmer Quarterly 7, 85-95.

Coll, R.A., 1994, Christianity and feminism in conversation, Twenty-Third Publication, Mystic, CT.
Countryman, L.W., [1988] 1989, Dirt, greed and sex: Sexual ethics in the New Testament and their implications for today, Second printing, Fortress, Philadelphia, PA.

Dreyer, T.F.J., 1998, 'Spiritualiteit, identiteit en die etos van die Hervormde Kerk', HTS Teologiese Studies 54(1\&2), 289-314.

Dreyer, Y., 1980, 'Pastorale berading en die Pastorale Verwysingsdiens: ' $n$ Kritiese evaluering', BD Skripsie, Dept. Praktiese Teologie, Universiteit van Pretoria.

Dreyer, Y., 1996, 'Bybelse huweliksrolle en die moderne egalitêre huwelik (Efesiërs 5:21-32)', Praktiese Teologie in Suid-Afrika 11(2), 95-103.

Dreyer, Y., 1998a, 'Pastorale interaksie met vroue: 'n Prakties-Teologiese begronding', DD proefskrif, Dept. Praktiese Teologie, Universiteit van Pretoria.

Dreyer, Y., 1998b, 'Pastorale interaksie met vroue - gesien vanuit die beelde wat vir God gebruik word', HTS Theological Studies 54(3\&4), 544-572. https://doi.org/ $10.4102 /$ hts.v54i3/4.1429

Dreyer, Y., 1999a, 'Die personaliteit van vrou-wees binne die Mediterreense kultuur', HTS Theological Studies 55(1), 48-69. https://doi.org/10.4102/hts.v55i1.1517

Dreyer, Y., 1999b, 'Jesus en Vroue', HTS Theological Studies 55(1), 70-96.

Dreyer, Y., 1999c, 'Vroue ervaring en spiritualiteit', HTS Theological Studies 55(2\&3), 360-379.

Dreyer, Y., 2000a, 'Vrou as beeld van God, Deel1: 'n Historiese ondersoek - Vanaf Genesis tot die Middeleeue', HTS Theological Studies 56(2\&3), 672-696.

Dreyer, Y., 2000b, 'Vrou as beeld van God: Vanaf die Reformasie tot die Twintigste eeu', HTS Theological Studies 56(4), 949-972. https://doi.org/10.4102/hts. v56i4.1800

Dreyer, Y., 2004, 'Homoseksualiteit: Die Kerk, die tradisie en die Bybel - homofobie, sarkofobie en die evangelie', HTS Theological Studies 60(1\&2), 175-205. https:// doi.org/10.4102/hts.v60i1/2.525

Dreyer, Y., 2005, 'Sexuality and shifting paradigms - Setting the scene', HTS Theological Studies 61(3), 729-751. https://doi.org/10.4102/hts.v61i3.471

Dreyer, Y., 2006, 'Heteronormatiwiteit, homofobie en homoseksualiteit - ' $n$ roetekaart vir 'n inklusiewe kerk', HTS Theological Studies 62(2), 445-471. https://doi. org/10.4102/hts.v62i2.375

Dreyer, Y., 2007a, 'Karl Barth's male-female order as assymetrical theoethics', HTS Theological Studies 63(3), 1493-1521.

Dreyer, Y., 2007b, 'Karl Barth's male-female order: A kingpin of dogmatic disparity', HTS Theological Studies 63(3), 1523-1547. https://doi.org/10.4102/hts.v63i4.266

Dreyer, Y., 2007c, 'Hegemony and the internalisation of homophobia caused by heteronormativity', HTS Theological Studies 63(1), 2-18. https://doi.org/10.4102/ hts.v63i1.197

Dreyer, Y., 2008a, 'The "sanctity" of marriage - An archaeology of a socio-religious construct: Mythological origins, forms and models', HTS Theological Studies 64(1), 499-527. https://doi.org/10.4102/hts.v64i1.10

Dreyer, Y., 2008b, “"De-centre-ing” sexual difference in public and ecclesial discourses on marriage', HTS Theological Studies 64(2), 715-738. https://doi.org/10.4102/ hts.v64i2.41

Dreyer, Y., 2008c, 'A pastoral response to the unhealed wound of gays exacerbated by indecision and inarticulacy', HTS Theological Studies 64(3), 1236-1254. https:// doi.org/10.4102/hts.v64i3.71

Dreyer, Y., 2011, 'Women's spirituality and feminist theology: A hermeneutic of suspicion applied to "patriarchal marriage"', HTS Theological Studies 67(3), Art. \#1104, 1-5. https://doi.org/10.4102/hts.v67i3.1104

Foucault, M., [1976] 1978, The history of sexuality, Vol 1: An introduction, transl. R. Hurley, Random House, New York.

Foucault, M., 1988, 'Truth, power, self: An interview with Michel Foucault, October 25, 1982', in L.H. Martin, H. Goodman \& P.H. Hutton (eds.), Technologies of the self: A seminar with Michel Foucault, pp. 9-15, University of Massachusetts Press, Amherst, MA.

Freud, S., 1938, 'Infantile sexuality', in The basic writings of Sigmund Freud, transl. A.A Brell, Modern Library, New York.

Garton, S., 2004, Histories of sexuality: Antiquity to sexual revolution, Equinox Publishing, London.

Gössmann, E., 1996, 'The construction of women's difference', in E. Schüssler Fiorenza (ed.), The power of naming: A Concilium reader in feminist liberation theology, pp. 198-207, SCM. Maryknoll, NY.

Habermas, J., [1981] 1984, The theory of communicative action, Vol 1: Reason and the rationalization of society, transl. T. McCarthy, Beacon, Boston, MA.

Jacobs-Malina, D., 1993, Beyond patriarchy: The images of family in Jesus, Paulist, New York.

Malina, B.J., [1981] 1993, The New Testament world; Insights from cultural anthropology, Revised edition, Westminster/John Knox, Louisville, KY.

Matthews, V.H. \& Bejamin, D.C., 1993, Social world of ancient Israel: 1250-587 BC, Hendrickson, Peabody, MA.

McCarthy, D.M., 2001, Sex and love in the home: A theology of the household, SCM, London.

McCarthy, D.M., 2002, 'The relationship of bodies: A nuptial hermeneutics of samesex union', in E. Rogers (ed.), Theology and sexuality: Classic and contemporary readings, pp. 200-216, Blackwell, Oxford.

Melcher, S.J., 1996, 'The Holiness Code and human sexuality', in R.L. Brawley (ed.), Biblical ethics \& homosexuality: Listening to Scripture, pp. 87-102, Westminster John Knox, Louisville, KY.

Nelson, J.B., 1992, The intimate connection: Male sexuality, masculine spirituality, Westminster Press, Philadelphia, PA. 
Ricoeur, P., [1986] 1991, From text to action: Essays in hermeneutics, II, transl. K. Blamey \& J.B. Thompson, Athlone, London.

Roberts, C.C., 2007, Creation and covenant: The significance of sexual difference in the moral theology of marriage, T \& T Clark International, New York.

Rogers, E., 2004, 'Sactified unions: An argument for gay marriage', Christian Century $121(12), 26-29$.

Ruether, R.R., 1975, New woman/New earth: Sexist ideologies and human liberation, Seabury, New York.

Ruether, R.R., 1983, Sexism and God-talk: Toward a feminist theology, Beacon, Boston, $M A$.

Ruether, R.R., 1991, 'Imago Dei, Christian tradition and feminist hermeneutics', in K.E. Børresen (ed.), Image of God and gender models in Judaeo-Christian tradition, Solum Forlag, Oslo.
Schertzberg, L., 1995, Grundkurs feministiche theologie, Matthias-Grünewald-Verlag, Mainz.

Schulenburg, A., 1993, Feministische spiritualität: Exodus in eine befreiende Kirche? Kohlhammer, Stuttgart.

Thatcher, A., 1999, Marriage after modernity: Christian marriage in postmodern times, Sheffield Academic Press, Sheffield.

Tillich, P., 1957, Systematic theology, vol. 2, Chicago University Press, Chicago, IL.

Via, D.O., 2003, 'The Bible, the church and homosexuality', in D.O. Via \& R.A.J. Gagnon (eds.), Homosexuality and the Bible, pp. 1-39, Fortress, Minneapolis, MN.

Ward, G., 1998, 'The erotics of redemption - After Karl Barth', Theology and Sexuality 8, 52-72. https://doi.org/10.1177/135583589800400805

Winkler, J.J., 1990, The constraints of desire: The anthropology of sex and gender in ancient Greece, Routledge, New York. 